\title{
View On Science and Education (VOSE): Studi Terhadap Mahasiswa Program S1 IPA-Fisika
}

\author{
${ }^{1}$ Mukhayyarotin Niswati Rodliyatul Jauhariyah, ${ }^{2}$ Khaerus Syahidi, ${ }^{3}$ Eti Sukadi, \\ ${ }^{4}$ Wirawan Fadly \\ ${ }^{1}$ Program Studi Pendidikan Fisika Universitas Negeri Surabaya, Jln. Ketintang, Surabaya, \\ Jawa Timur, 60321 \\ ${ }^{2}$ Prodi Pendidikan Fisika, FMIPA, Universitas Hamzanwadi, Jln. TGKH. M. Zainuddin Abdul \\ Madjid No. 132 Pancor Selong, Lombok Timur, NTB, 83611 \\ ${ }^{3}$ Program Studi Pendidikan Fisika IKIP PGRI Pontianak, Jl. Ampera No.88, Sungai Jawi, \\ Kec. Pontianak Kota, Kota Pontianak, Kalimantan Barat 78116 \\ ${ }^{4}$ Tadris IPA IAIN Ponorogo, Jl. Puspita Jaya, Krajan, Pintu, Kec. Jenangan, Kabupaten \\ Ponorogo, Jawa Timur 63492 \\ Email Korespondensi: mukhayyarotinjauhariyah@unesa.ac.id
}

\begin{tabular}{|c|c|}
\hline & $c t$ \\
\hline $\begin{array}{l}\text { Article History } \\
\text { Received: December } 2020 \\
\text { Revised: December } 2020 \\
\text { Published: December } 2020\end{array}$ & \multirow{2}{*}{$\begin{array}{l}\text { This study aims to examine the concept of the nature of science (NOS) and } \\
\text { attitudes towards teaching the NOS. The research used the View on Science } \\
\text { Education (VOSE) instrument that was developed by Chen (valid and reliable) } \\
\text { which online distributed to students of Physics Education Program from } \\
\text { Surabaya State University and IKIP PGRI Pontianak, as well as students of } \\
\text { Science Program from IAIN Ponorogo. The survey research method was } \\
\text { conducted to determine the profile of students' views on the NOS and science } \\
\text { education. Respondents who filled out the research questionnaire were } 102 \\
\text { students. Based on the survey results, the VOSE profile was obtained that the } \\
\text { Science-Physics students had difficulty conceptualizing the general picture of } \\
\text { VOSE because in some aspects of NOS it appeared that students experienced } \\
\text { confusion.Science-Physics students have a positive attitude towards teaching } \\
\text { NOS in terms of tentativeness, aspect of the nature of observation, as well as } \\
\text { aspect of theory and law.However, Science-Physics students have negative } \\
\text { attitudes towards teaching NOS in the aspect of the scientific method. Thus, the } \\
\text { implication of this research requires that Science-Physics students learn and } \\
\text { further research about the concept of NOS in order to have a correct } \\
\text { understanding. }\end{array}$} \\
\hline & \\
\hline & \\
\hline & \multirow{2}{*}{$\begin{array}{l}\text { Penelitian ini bertujuan untuk mengkaji konsep tentang hakikat sains dan sikap } \\
\text { terhadap pengajaran hakikat sains. Penelitian menggunakan instrumen View } \\
\text { on Science and Education (VOSE) yang telah dikembangkan oleh Chen yang } \\
\text { disebarkan secara daring kepada mahasiswa Pendidikan Fisika Universitas } \\
\text { Negeri Surabaya dan IKIP PGRI Pontianak, serta mahasiswa IPA IAIN } \\
\text { Ponorogo. Metode penelitian survei dilakukan untuk mengetahui profil } \\
\text { pandangan mahasiswa terhadap hakikat sains dan pendidikan sains. Responden } \\
\text { yang mengisi kuesioner penelitian ini sejumlah } 102 \text { mahasiswa. Berdasarkan } \\
\text { hasil survei, diperoleh profil VOSE bahwa mahasiswa IPA-Fisika mengalami } \\
\text { kesulitan dalam mengkonseptualisasikan gambaran umum VOSE karena pada } \\
\text { beberapa aspek NOS tampak bahwa mahasiswa mengalami kebingungan. } \\
\text { Mahasiswa IPA-Fisika memiliki sikap positif terhadap pengajaran NOS pada } \\
\text { aspek tentativeness, aspek hakikat observasi, serta aspek teori dan hukum. } \\
\text { Namun, mahasiswa IPA-Fisika memiliki sikap negatif terhadap pengajaran } \\
\text { NOS pada aspek metode ilmiah. Dengan demikian, implikasi penelitian ini } \\
\text { mengharuskan mahasiswa IPA-Fisika belajar dan meneliti lebih lanjut tenttang }\end{array}$} \\
\hline & \\
\hline
\end{tabular}




\section{PENDAHULUAN}

Abad ke-21 merupakan era persaingan ketat di bidang sains. Oleh karena itu, pendidikan di abad ke-21 harus mengacu kepada keterampilan abad ke-21 dengan tetap memperhatikan hakikat sains itu sendiri. Perkembangan pendidikan di abad ini harus ditekankan Pembelajaran IPA yang bertujuan untuk mengembangkan keterampilan literasi sains pada siswa (OECD, 2013). Kemampuan literasi sains menjadi tolok ukur pertumbuhan ekonomi dan digunakan untuk menemukan solusi untuk masalah sosial dan lingkungan yang kompleks (OECD, 2015). Namun, literasi sains siswa di Indonesia masih sangat rendah. PIS A 2015 menunjukkan bahwa kompetensi literasi sains siswa Indonesia berada pada level yang rendah (OECD, 2015). PISA 2018 menunjukkan bahwa literasi sains masih di level 1 (Schleicher, 2019). Hal ini menunjukkan bahwa perlu dicari penyebab rendahnya keilmuan tersebut keterampilan literasi siswa di Indonesia.

Dalam kajian lain yang terkait dengan literasi sains, pengertian hakikat sains atau Nature of Science (NOS) adalah sebuah komponen penting dan utama dari literasi sains (Lederman, 1992; Abd-El-Khalick dan BouJaoude, 1997; Abd-El-Khalick dan Lederman, 2000; Abd-ElKhalick et.al., 2002; Sangsa-ard et.al., 2014). Abd-El-Khalick et.al (2002) dan Bilican et.al. (2012) menyatakan bahwa seseorang yang memiliki keterampilan literasi sains akan memiliki kemampuan memahami konsep, teori, prinsip, dan hakikat sains, pengembangan sains, dan mewujudkan keterkaitan antar ilmu pengetahuan, teknologi, dan masyarakat (orang yang literat). Lederman menyatakan bahwa NOS merupakan epistemologi ilmu dimana ilmu merupakan cara untuk memperoleh ilmu,atau nilai-nilai dan keyakinan yang melekat pada pengetahuan ilmiah atau perkembangan ilmu (Lederman dan Lederman, 2004). Karena itu, NOS atau Hakikat Sains sangat perlu mendapat perhatian dalam pembelajaran IPA, tidak terkecuali pembelajaran Fisika.

Penelitian sebelumnya menunjukkan bahwa pemahaman siswa kelas 10 SMA terhadap hakikat sains masih dalam kategori cukup (Jauhariyah et.al., 2020). Potret penelitian tersebut dapat menjawab beberapa pendapat ilmuwan yang menemukan bahwa NOS jarang diajarkan secara detail oleh guru sehingga siswa belum memiliki pemahaman yang baik terhadap hakikat sains. Siswa cenderung diminta untuk belajar mandiri untuk memahami hakikat sains. Padahal, di sisi lain, NOS merupakan dasar yang perlu diajarkan dengan baik oleh guru. McComas (2015) menyatakan bahwa NOS adalah bagian yang sering diabaikan dari pengajaran sains, namun NOS memberikan latar belakang yang penting bagi siswa, merinci bagaimana sains dan ilmuwan bekerja dan bagaimana pengetahuan ilmiah dibuat, divalidasi, dan dipengaruhi.

Beberapa penelitian menunjukkan bahwa pemahaman siswa tentang NOS cukup rendah. Hasil penelitian Bell (2008) menunjukkan bahwa siswa dan guru belum memiliki pemahaman yang sesuai tentang hakikat sains. Penelitian lain oleh Abd-El-Khalick et.al (2002) secara umum menunjukkan bahwa siswa TK hingga siswa kelas 12 dan juga guru belum mencapai pemahaman tentang hakikat sains. Beberapa studi menunjukkan bahwa guru pra-jabatan umumnya memiliki pemahaman parsial hakikat sains (Jain et.al., 2013), sehingga perlu adanya upaya peningkatan muatan pedagogik calon guru IPA-Fisika. Pengetahuan untuk mengajar hakikat sains harus lebih menekankan pada strategi untuk menilai hakikat sains dan bagaimana mengintegrasikan hakikat sains secara eksplisit ke dalam konten sains 
(Bilican et.al., 2012). Temuan lainnya, sebagian besar guru mengakui bahwa pengetahuannya tentang hakikat sains tidak mencukupi tetapi juga menyatakan bahwa hakikat sains penting dalam pengajaran sains (Mihladız dan Dogan, 2014). Jiang dan McComas (2014) menyatakan bahwa salah satu faktor masalahnya mungkin karena hampir semua buku teks sains fokus pada pengetahuan ilmiah, sedangkan investigasi ilmiah, pemikiran ilmiah dan aspek sosial ilmu kurang mendapat perhatian.

Fakta tersebut menunjukkan perlunya investigasi lebih lanjut terkait penyebab kurangnya pemahaman siswa terhadap hakikat sains. Berdasarkan temuan McComas, perlu juga mengetahui sejauh mana pandangan terhadap pentingnya mengajarkan hakikat sains. Investigasi tidak dilakukan kepada guru dan siswa secara langsung, namun dilakukan kepada mahasiswa calon guru IPA dan calon guru Fisika. Pemetaan profil pandangan terhadap hakikat sains dan pendidikan sains sejak dini diharapkan dapat memberikan refleksi bagi pencetak guru IPA-Fisika agar dapat menghasilkan lulusan yang memiliki pemahaman yang baik terhadap hakikat sains dan pentingnya mengajarkan hakikat sains pada siswa.

Untuk membantu investigasi terhadap pandangan sains dan pendidikan sains oleh mahasiswa Pendidikan IPA-Fisika, diperlukan instrumen yang tepat. Chen (2006) telah mengembangkan sebuah kuesioner bernama VOSE (View on Science and Education) yang fokus terhadap aspek NOS dan isu tentang sikap terhadap pentingnya mengajarkan sains. Aspek NOS yang terdapat dalam kuesioner VOSE yang telah dikembangkan Chen (2006) adalah (1) tentativeness pengetahuan ilmiah, (2) hakikat observasi, (3) metode ilmiah, (4) hipotesis, hukum, dan teori, (5) imajinasi, (6) validasi pengetahuan ilmiah, (7) objektivitas dan subjektivitas dalam sains. Selain tujuh aspek tersebut, VOSE terdiri dari tiga (3) bagian, yaitu pandangan tentang apa itu NOS atau hakikat sains, pandangan tentang apa yang diharapkan dari NOS, dan pandangan tentang pendidikan sains serta kaitannya dengan NOS. VOSE yang telah dikembangkan dan memenuhi kriteria standar kuesioner yang baik langsung digunakan untuk memotret profil pandangan mahasiswa rogram IPA-Fisika terhadap sains dan pendidikan sains.

\section{METODE}

Penelitian ini merupakan penelitian survey untuk mendeskripsikan secara kuantitatif tentang pandangan mahasiswa program IPA-Fisika terhadap sains dan pendidikan sains. Survei dilakukan menggunakan kuesioner VOSE yang telah dikembangkan oleh Chen (2006) melalui media WhatsApp. Sasaran survei ini adalah mahasiswa seluruh tingkat yang diambil dari 3 kampus, yakni mahasiswa program studi S1 Pendidikan Fisika Universitas Negeri Surabaya, mahasiswa program S1 Pendidikan Fisika IKIP PGRI Pontianak, dan mahasiswa program studi S1 Tadris IPA IAIN Ponorogo. Kuesioner diberikan secara acak kepada seluruh responden, terdapat 102 responden yang bersedia mengisi kuesioner VOSE yang disebarkan oleh tim penelitian dengan bantuan komunikasi WhatsApp pada semester gasal tahun 2019/2020.

Kuesioner VOSE telah diuji reliabilitasnya dan termasuk dalam kategori reliabel (Sumranwanich dan Yuenyong, 2014). Instrumen kuesioner VOSE dapat diandalkan (reliabel) karena item tersebut berasal dari sudut pandang responden dan bukan dari anggapan pada ahli tentang tanggapan yang masuk akal. Reliabilitas test-retest memiliki koefisien korelasi tinggi, yakni sebesar 0,82. Skor Cronbach Alpha dari semua item NOS di VOSE berkisat antara 0,34 sampai 0,81 dan digunakan untuk memverifikasi kesesuaian serta membuang beberapa item (yang bukan kriteria utama) dalam uji coba. Untuk validitas, isi dan interpretasi item divalidasi oleh dua panel ahli yang masing-masing panel terdiri dari enam ahli (Chen, 2006).

VOSE menilai pandangan responden terhadap konsep NOS dekaligus sikap terhadap pengajaran NOS. Secara umum, kuesioner VOSE terdiri dari 3 (tiga) bagian, yaitu pandangan terhadap apa itu NOS, pandangan tentang apa yang seharusnya menjadi NOS, dan pandangan tentang pendidikan sains yang terkait erat dengan NOS. Setiap pertanyaan VOSE diikuti oleh beberapa item yang merepresentasikan posisi filosofis yang berbeda. Responden diinstruksikan untuk membaca semua item pertanyaan sebelum memilih jawaban. 
Tabel 1 menunjukkan keterkaitan antara item pertanyaan dalam kuesioner VOSE dengan aspek NOS dan filosofi pendidikan sains. Setiap aspek diwakili oleh beberapa item soal yang jawaban dari responden dapat dianalisis untuk mengetahui sejauh mana posisi pandangan responden terhadap NOS dan pendidikan sains.

Tabel 1. Keterkaitan antara Aspek NOS, Posisi filosofis, dan Nomor item dalam VOSE (diadaptasi dari Chen, 2006)

\begin{tabular}{|c|c|c|}
\hline Topik & Posisi Filosofis & Item \\
\hline \multirow{3}{*}{ Tentativeness } & Revolusioner & $4 \mathrm{~A}$ \\
\hline & Kumulatif & 4B \\
\hline & Evolusioner & $4 \mathrm{C}$ \\
\hline \multirow[t]{2}{*}{ Sifat observasi } & Teori laden & $8 \mathrm{~A}, 8 \mathrm{~B}, 8 \mathrm{E}$ \\
\hline & Teori independen & $8 \mathrm{C}, 8 \mathrm{D}$ \\
\hline \multirow[t]{2}{*}{ Metode ilmiah } & Metode ilmiah universal & 9A, 9B, 9F \\
\hline & Beragam metode & 9C, 9D, 9E \\
\hline \multirow[t]{7}{*}{ Teori dan hukum } & Epistemologi & \\
\hline & Ditemukan (discovered) & $\begin{array}{l}\text { 5A, 5B (teori) 6A, 6B } \\
\text { (hukum) }\end{array}$ \\
\hline & Diciptakan (invented) & $\begin{array}{l}\text { 5D, 5E, 5F (teori) 6D, 6E } \\
\text { (hukum) }\end{array}$ \\
\hline & $\begin{array}{l}\text { Ditemukan atau diciptakan } \\
\text { (discovered or invented) }\end{array}$ & 5C (teori) 6C (hukum) \\
\hline & Perbandingan & \\
\hline & Hukum menjadi lebih pasti & $7 \mathrm{~A}, 7 \mathrm{~B}$ \\
\hline & Berbagai jenis ide & 7C, 7D \\
\hline \multirow[t]{2}{*}{ Penggunaan imajinasi } & $\mathrm{Ya}$ & $3 \mathrm{~A}, 3 \mathrm{~B}$ \\
\hline & Tidak & $3 \mathrm{C}, 3 \mathrm{D}, 3 \mathrm{E}$ \\
\hline \multirow{5}{*}{$\begin{array}{l}\text { Validasi pengetahuan } \\
\text { ilmiah }\end{array}$} & Bukti empiris & $1 \mathrm{~A}, 1 \mathrm{H}$ \\
\hline & Paradigma & $1 \mathrm{C}, 1 \mathrm{~F}$ \\
\hline & Penghematan & 1D \\
\hline & Wewenang & $1 \mathrm{E}$ \\
\hline & Intuisi & $1 \mathrm{G}$ \\
\hline \multirow{16}{*}{$\begin{array}{l}\text { Subjektivitas dan } \\
\text { objektivitas }\end{array}$} & Subjektivitas & \\
\hline & Penghematan (parsimony) & 1D (sebenarnya) \\
\hline & Wewenang & 1E (sebenarnya) \\
\hline & Paradigma & 1C, 1F, 8A, 8B (sebenarnya) \\
\hline & Faktor pribadi & 1G, 8A (sebenarnya) \\
\hline & Pengaruh sosial budaya & 2A, 2B (sebenarnya) \\
\hline & Imaginasi & 3A, 3B (sebenarnya) \\
\hline & Metodologi & 9D (sebenarnya) \\
\hline & Netral & 1B (sebenarnya) \\
\hline & Objektivitas & \\
\hline & Tidak ada pengaruh sosiokultural & 2C, 2D (sebenarnya) \\
\hline & Tidak menggunakan imajinasi & 3C, 3E (sebenarnya) \\
\hline & Berdasarkan fakta eksperimental & 5B, 6B, 8D (sebenarnya) \\
\hline & $\begin{array}{l}\text { Tidak ada pengaruh keyakinan } \\
\text { pribadi }\end{array}$ & 8C (sebenarnya) \\
\hline & Metodologi & 8E, 9A, 9B (sebenarnya) \\
\hline & Secara keseluruhan & 1A, 1H (sebenarnya) \\
\hline
\end{tabular}

Tabel 2. Sikap terhadap pengajaran topik NOS diuji oleh VOSE (diadaptasi dari Chen, 2006) Topik 


\begin{tabular}{lll}
\hline Tentativeness & $\begin{array}{l}\text { Mengajar tentativeness pengetahuan } \\
\text { ilmiah }\end{array}$ & $12 \mathrm{~A}, 12 \mathrm{~B}$ \\
\cline { 2 - 3 } & $\begin{array}{l}\text { Hindari mengajarkan tentativeness } \\
\text { pengetahuan ilmiah }\end{array}$ & $12 \mathrm{C}, 12 \mathrm{D}, 12 \mathrm{E}$ \\
\hline Sifat observasi & $\begin{array}{l}\text { Melatih siswa untuk melakukan } \\
\text { observasi yang obyektif }\end{array}$ & $11 \mathrm{~A}, 11 \mathrm{~B}, 11 \mathrm{C}$ \\
\cline { 2 - 3 } & $\begin{array}{l}\text { Mengungkap sifat observasi yang sarat } \\
\text { teori }\end{array}$ & $11 \mathrm{D}, 11 \mathrm{E}$ \\
\hline Metode ilmiah & Mengajar metode ilmiah universal & $10 \mathrm{~A}, 10 \mathrm{~B}, 10 \mathrm{C}, 10 \mathrm{D}$, \\
& Mendorong metode yang berbeda & $10 \mathrm{G}, 10 \mathrm{H}, 10 \mathrm{I}$ \\
\hline Teori dan hukum & $\begin{array}{l}\text { Mengajar hubungan antara teori dan } \\
\text { hukum }\end{array}$ & $13 \mathrm{~A}, 13 \mathrm{~B}$ \\
\cline { 2 - 3 } & Hindari mengajarkan hubungan & $13 \mathrm{C}, 13 \mathrm{D}$ \\
\hline
\end{tabular}

\section{HASIL DAN PEMBAHASAN}

Instrumen VOSE yang diberikan kepada mahasiswa dalam bentuk google form terdiri dari 13 pertanyaan dengan masing-masing memiliki pilihan jawaban yang memiliki topik NOS sesuai dengan kategori pada Tabel 1 dan Tabel 2. Berdasarkan instrumen VOSE yang diberikan kepada sejumlah mahasiswa di 3 perguruan tinggi, diperoleh rekapitulasi hasil jawaban responden yang disajikan pada Tabel 3 sampai Tabel 15.

Tabel 3. Tanggapan dari pertanyaan nomor 1

1. Ketika dua teori berbeda muncul untuk menjelaskan fenomena yang sama (mis., Fosil dinosaurus, teori cahaya) akankah para ilmuwan menerima dua Frekuensi teori pada saat yang sama?

A. Ya, karena para ilmuwan masih tidak dapat secara obyektif menentukan mana yang lebih baik; oleh karena itu, mereka akan menerima keduanya untuk sementara.

B. Ya, karena kedua teori tersebut dapat memberikan penjelasan dari sudut pandang yang berbeda, tidak ada yang paling benar atau salah.

C. Tidak, karena para ilmuwan cenderung menerima teori yang lebih mereka 3 kenal.

D. Tidak, karena para ilmuwan cenderung menerima teori yang lebih sederhana $\quad 0$ dan menghindari teori yang kompleks.

E. Tidak, status akademik dari masing-masing pengusul teori dengan pengaruh 5 penerimaan ilmuwan terhadap teori.

F. Tidak, para ilmuwan cenderung menerima teori-teori baru yang sedikit menyimpang dari inti ilmiah kontemporer teori.

G. Tidak, para ilmuwan menggunakan intuisi untuk membuat penilaian. 2

H. Tidak, karena hanya ada satu kebenaran, para ilmuwan tidak akan menerima $\quad 18$ teori apa pun sebelum membedakan manayang paling baik.

Tabel 4. Tanggapan dari pertanyaan nomor 2

2. Investigasi ilmiah dipengaruhi oleh nilai-nilai sosial-budaya (mis., Tren saat Frekuensi ini, nilai-nilai).

A. Ya, nilai-nilai sosial budaya mempengaruhi arah dan topik investigasi 35,6 ilmiah.

B. Ya, karena para ilmuwan yang berpartisipasi dalam penyelidikan ilmiah 19,8 dipengaruhi oleh nilai-nilai sosial budaya. 
C. Tidak, ilmuwan dengan pelatihan yang baik akan tetap bebas nilai ketika melakukan penelitian.

D. Tidak, karena sains membutuhkan objektivitas, yang bertentangan dengan

nilai-nilai sosial-budaya subyektif.

\section{Lainnya}

Tabel 5. Tanggapan dari pertanyaan nomor 3

3. Ketika para ilmuwan melakukan penelitian ilmiah, akankah mereka menggunakan imajinasi mereka?

A. Ya, imajinasi adalah sumber utama inovasi.

B. Ya, para ilmuwan menggunakan imajinasi mereka kurang lebih dalam

22,8 penelitian ilmiah.

C. Tidak, imajinasi tidak konsisten dengan prinsip logis sains.

D. Tidak, imajinasi dapat menjadi sarana bagi seorang ilmuwan untuk membuktikan maksudnya dengan cara apa pun.

E. Tidak, imajinasi tidak memiliki keandalan.

Lainnya

0

Tabel 6. Tanggapan dari pertanyaan nomor 4

4. Sekalipun investigasi ilmiah dilakukan dengan benar, teori yang diajukan masih bisa dibantah di masa depan.

A. Penelitian ilmiah akan menghadapi perubahan revolusioner, dan teori lama $\quad 37,4$ akan diganti.

B. Kemajuan ilmiah tidak dapat dibuat dalam waktu singkat. Itu melalui proses

kumulatif; oleh karena itu, teori lama dipertahankan.

C. Dengan akumulasi data dan informasi penelitian, teori akan berkembang $\quad 44,4$ lebih akurat dan sepenuhnya, tidak dibantah.

Tabel 7. Tanggapan dari pertanyaan nomor 5

5. Apakah teori ilmiah (mis. Seleksi alam, teori atom) "ditemukan" atau Frekuensi

"diciptakan" oleh para ilmuwan dari alam?

A. Ditemukan, karena ide itu ada di sana sepanjang waktu untuk diungkap.

10,9

B. Ditemukan, karena didasarkan pada fakta eksperimental. 29,7

C. Beberapa ilmuwan menemukan teori secara tidak sengaja, tetapi ilmuwan 27,7 lain dapat menciptakan teori dari fakta yang mereka ketahui.

D. Diciptakan, karena teori adalah interpretasi dari fakta eksperimental, dan $\quad 28,7$ fakta eksperimental adalah ditemukan oleh para ilmuwan.

E. Diciptakan, karena sebuah teori diciptakan atau dikerjakan oleh para ilmuwan.

F. Diciptakan, karena suatu teori dapat dibantah.

Tabel 8. Tanggapan dari pertanyaan nomor 6

6. Apakah hukum ilmiah (mis. Hukum gravitasi) "ditemukan" atau Frekuensi "diciptakan" oleh para ilmuwan dari dunia alami?

A. Ditemukan, karena hukum ilmiah ada di luar sana di alam, dan para ilmuwan hanya harus menemukannya.

B. Ditemukan, karena hukum ilmiah didasarkan pada fakta eksperimental. 34

C. Beberapa ilmuwan menemukan hukum secara tidak sengaja, tetapi ilmuwan 
lain mungkin menemukan hukum dari yang diketahui fakta.

D. Diciptakan, karena para ilmuwan menciptakan hukum ilmiah untuk 18 menafsirkan fakta eksperimental yang ditemukan.

E. Diciptakan, karena tidak ada yang absolut di alam, oleh karena itu, hukum 1 ditemukan oleh para ilmuwan.

Tabel 9. Tanggapan dari pertanyaan nomor 7

7. Dibandingkan dengan hukum, teori memiliki lebih sedikit bukti untuk Frekuensi mendukungnya.

$(\%)$

A. Ya, teori tidak pasti seperti hukum.

10,1

B. Ya, jika sebuah teori menghadapi banyak ujian, pada akhirnya akan menjadi $\quad 58,6$ hukum, oleh karena itu, hukum memiliki lebih banyak bukti pendukung.

C. Tidak sepenuhnya, beberapa teori memiliki lebih banyak bukti yang mendukung daripada beberapa hukum.

D. Tidak, teori dan hukum adalah berbagai jenis ide. Keduanya tidak bisa

16,2 dibandingkan.

Tabel 10. Tanggapan dari pertanyaan nomor 8

8. Pengamatan ilmuwan dipengaruhi oleh keyakinan pribadi (misalnya, Frekuensi pengalaman pribadi, anggapan); karena itu, mereka mungkin tidak melakukan pengamatan yang sama untuk percobaan yang sama.

A. Pengamatan akan berbeda, karena keyakinan yang berbeda menyebabkan harapan yang berbeda mempengaruhi pengamatan.

B. Pengamatan akan sama, karena para ilmuwan yang dilatih di bidang yang sama memiliki ide yang sama.

C. Pengamatan akan sama, karena melalui pelatihan ilmiah para ilmuwan dapat meninggalkan pribadi nilai-nilai untuk melakukan pengamatan objektif.

D. Pengamatan akan sama, karena pengamatan adalah persis apa yang kita lihat dan tidak lebih. Fakta adalah fakta. Interpretasi mungkin berbeda dari satu orang ke orang lain, tetapi pengamatan harus menjadi sama.

E. Pengamatan akan sama. Meskipun subjektivitas tidak dapat sepenuhnya dihindari dalam observasi, ilmuwan menggunakan metode berbeda untuk memverifikasi hasil dan meningkatkan objektivitas.

Tabel 11. Tanggapan dari pertanyaan nomor 9

9. Sebagian besar ilmuwan mengikuti metode ilmiah universal, langkah

demi langkah, untuk melakukan penelitian mereka (yaitu, menyatakan Frekuensi

hipotesis, rancang percobaan, mengumpulkan data, dan membuat kesimpulan)

A. metode ilmiah memastikan hasil yang valid, jelas, logis dan akurat. Jadi, sebagian besar ilmuwan mengikuti metode universal dalam penelitian.

B. Kebanyakan ilmuwan menggunakan metode ilmiah karena ini adalah prosedur yang logis.

C. Metode ilmiah berguna dalam banyak kasus, tetapi tidak menjamin hasil; oleh karena itu, para ilmuwan menemukan metode baru.

D. Tidak ada yang disebut metode ilmiah. Ilmuwan menggunakan metode apa pun untuk mendapatkan hasil.

E. Tidak ada metode ilmiah yang pasti; pengetahuan ilmiah dapat ditemukan secara tidak sengaja.

F. Tidak peduli bagaimana hasilnya diperoleh, para ilmuwan menggunakan metode ilmiah untuk memverifikasinya. 
Tabel 12. Tanggapan dari pertanyaan nomor 10

10. Siswa di sekolah menengah pertama dan atas harus mempelajari prosedur metode ilmiah.

Frekuensi

$(\%)$

A. Ya, jadi siswa memiliki pedoman untuk bekerja. $\quad 16,5$

B. Ya, karena para siswa masih tidak mampu untuk mengembangkan sesuai

5,2 secara fair.

C. Ya, mereka harus mempelajari apa yang dilakukan para ilmuwan.

D. Ya, karena metode ilmiah adalah metode terbaik yang telah dikembangkan $\quad 16,5$ para ilmuwan sejauh ini.

E. Ya, ini membantu siswa untuk belajar cara obyektif belajar sains.

F. Ya, ini dapat membantu siswa untuk memahami esensi sains.

47,4

G. Tidak, kita seharusnya tidak hanya mengajarkan satu metode ilmiah. Siswa

7,2

4,1 harus diberi ruang untuk berpikir dan mengembangkan metode mereka sendiri.

H. Tidak, tidak ada yang disebut metode ilmiah

I. Tidak, para guru dan siswa harus melakukan brainstorming metode penelitian yang berbeda bersama-sama.

Tabel 13. Tanggapan dari pertanyaan nomor 11

11. Di kelas-kelas sains SMP dan SMA, ketika siswa mengamati kejadian yang sama, guru harus mengharapkan siswa untuk menemukan temuan yang sama.

A. Ya, guru harus menyarankan siswa untuk melakukan pengamatan objektif untuk mendapatkan temuan yang identik.

B. Ya, jika siswa cukup berhati-hati, mereka harus sampai pada temuan yang 0

0 sama.

C. Ya, fakta eksperimental tidak akan berbeda dengan orang tersebut, jadi tidak

peduli siapa yang melakukan pengamatan, hasilnya akan selalu sama.

D. Tidak, pengamatan akan dipengaruhi oleh prasangka siswa. 9,2

E. Tidak, guru harus berdiskusi dengan siswa bagaimana pengamatan dapat dipengaruhi oleh prasangka.

Lainnya

Tabel 14. Tanggapan dari pertanyaan nomor 12

12. Siswa harus memahami bahwa pengetahuan ilmiah dapat berubah. Frekuensi

A. Ya, jadi mereka menyadari sifat sains yang sebenarnya.

11,3

B. Ya, jadi mereka menyadari alasan mengapa sains terus berkembang.

83,5

C. Tidak, itu akan mengurangi minat siswa dalam belajar sains.

0

D. Tidak, itu akan mengurangi penerimaan siswa terhadap sains.

2,1

E. Tidak, para siswa hanya perlu belajar tentang dasar-dasar pengetahuan

3,1 ilmiah yang konstan.

Tabel 15. Tanggapan dari pertanyaan nomor 13

13. Pembelajaran sains di sekolah menengah harus menyelidiki definisi dan Frekuensi hubungan antara hipotesis, teori, dan hukum.

A. Ya, karena mereka mewakili struktur pengetahuan ilmiah. 26,5

B. Ya, karena itu adalah dasar dari penyelidikan ilmiah. 65,3

C. Tidak, mengetahui definisi dan hubungan antara istilah-istilah ini tidak 2 banyak membantu belajar pengetahuan ilmiah. 
D. Tidak, karena hipotesis, teori, dan hukum tidak memiliki makna yang pasti.

Konsep NOS dan sikap terhadap pengajaran NOS telah dinilai melalui kuesioner VOSE. Pada bagian ini akan dibahas pandangan tentang konsep NOS dan sikap terhadap pengajaran NOS bagi para mahasiswa IPA-Fisika yang berasal dari Unesa, IKIP PGRI Pontianak, dan IAIN Ponorogo. Berdasarkan data hasil penelitian dapat diketahui pandangan mahasiswa dalam setiap aspek NOS. Terdapat 7 aspek NOS yang perlu dikaji berdasarkan pandangan mahasiswa melalui jawaban kuesioner VOSE.

1. Posisi filosofis pada aspek tentativeness

Pandangan filosofis responden terhadap NOS untuk aspek tentativeness dapat dilihat dari jawaban pertanyaan keempat, "Sekalipun investigasi ilmiah dilakukan dengan benar, teori yang diajukan masih bisa dibantah di masa depan". Tabel 6 menunjukkan data pandangan filosofis mahasiswa IPA-Fisika pada aspek tentativeness pada penelitian ini. Lebih dari 44\% mahasiswa berada pada posisi evolusioner, 37,4\% memilih posisi revolusioner dan sisanya berada pada posisi kumulatif.

2. Posisi filosofis pada aspek hakikat observasi

Observasi adalah teori laden (Sumranwanich dan Yuenyong, 2014). Therefore, observations may be affected by the observer's anticipation and preconceptions. Tabel 10 menunjukkan bahwa sebagian besar mahasiswa IPA-Fisika sebagai responden penelitian ini menunjukkan pandangan bahwa onservasi adalah teori laden. Sekitar 38\% responden memilih 8E dan sekitar $37 \%$ memilih 8A yang keduanya merupakan pernyataan yang menunjukkan posisi filosofis pada teori laden. Sekitar 10\% (memilih 8C) dan $12 \%$ (memilih 8D) menunjukkan pandangan filosofis pada posisi teori independen terhadap hakikat observasi.

3. Posisi filosofis pada aspek metode ilmiah

NOS mengindikasikan bahwa tidak ada metode ilmiah yang universal (Sumranwanich dan Yuenyong, 2014). Faktanya, para ilmuwan menerapkan berbagai metode untuk melakukan penelitiannya. Namun, sebagian besar mahasiswa Pendidikan IPA-Fisika sebagai responden penelitian ini menunjukkan pandangan bahwa metode ilmiah bersifat universal. Hampir 70\% responden memilih pernyataan 9A, sekitar 19\% memilih 9B, dan sekitar 4\% memilih 9F yang ketiganya merupakan pernyataan yang menunjukkan posisi filosofis pada pandangan dan 3\% (memilih 9C) yang menunjukkan pandangan bahwa terdapat beragam metode dalam metode ilmiah.

4. Posisi filosofis pada aspek teori dan hukum

Hukum digunakan untuk mengekspesikan tentang apa saja yang telah diamati dan untuk memprediksi hal-hal yang belum diamati (Sumranwanich dan Yuenyong, 2014). Teori didefisisikan sebagai sebuah penjelasan dari fenomena dan hukum-hukum yang terkait (Chen, 2006; McComas, 1996).

Mempertimbangkan epistemologi teori dan hukum, secara luas dipersepsikan bahwa teori dan hukum diciptakan oleh ilmuwan untuk menafsirkan dan mendeskripsikan fenomena (Sumranwanich dan Yuenyong, 2014). Tabel 7 menunjukkan bahwa mahasiswa IPA-Fisika sebagian besar mempersepsikan bahwa teori dibuat oleh ilmuwan ( $27,7 \%$ responden memilih $5 \mathrm{C}$ dan $28,7 \%$ responden memilih 5D). Namun, temuan ini cukup membingungkan karena pada Tabel 8 menunjukkan bahwa sebagian besar mahasiswa IPA-Fisika memposisikan epistemologi hukum dan teori dalam kategori discovered (28\% responden memilih $6 \mathrm{~A}$ dan $34 \%$ memilih $6 \mathrm{~B}$ ). Beberapa responden yang memilih 6C (19\%) dan 6D (18\%) menunjukkan bahwa teori dan hukum berada pada posisi filosofis discovered or invented. Ini menunjukkan bahwa posisi mereka tentang epistemologi teori dan hukum berada pada posisi yang membingungkan. 
Teori dan hukum adalah dua jenis pengetahuan yang berbeda, keduanya memiliki bukti pendukung yang substansial dan yang satu tidak menjadi yang lainnya (Sumranwanich dan Yuenyong, 2014). Tabel 9 menunjukkan bahwa mayoritan mahasiswa IPA-Fisika sebagai responden penelitian ini memposisikan pandangannya bahwa hukum menjadi lebih pasti $(58,6 \%$ memilih $7 \mathrm{~B})$, hanya sedikit responden yang memposisikan bahwa hukum dan teori tidak dapat dibandingkan karena merupakan berbagai jenis ide $(16,2 \%$ memilih 7D).

5. Posisi filosofis pada aspek penggunaan imajinasi

Ilmuwan menggunakan imajinasi bersama dengan logika dan pengetahuan sebelumnya untuk menghasilkan pengetahuan ilmiah baru (Sumranwanich dan Yuenyong, 2014). Tabel 5 menunjukkan bahwa sebagian besar mahasiswa IPA-Fisika sebagai responden memiliki pandangan filosofis bahwa ilmuwan menggunakan imajinasi. Sejumlah 29,6\% responden memilih pernyataan $3 \mathrm{~A}$ dan $22,8 \%$ responden memilih pernyataan $3 \mathrm{~B}$.

6. Posisi filosofis pada aspek validasi pengetahuan ilmiah

Isu ini merefleksikan tentang bagaimana teori diterima oleh komunitas ilmiah. Tabel 3 menunjukkan bahwa sebagian besar mahasiswa IPA-Fisika memiliki pandangan filosofis bahwa validasi pengetahuan ilmiah berdasarkan bukti-bukti empiris (25\% memilih $1 \mathrm{~A}$ dan $18 \%$ memilih $1 \mathrm{H}$ ). Namun, sebuah teori tidak hanya dievaluasi berdasarkan hasil empiris tetapi juga berdasarkan pilihan komunitas ilmiah dalam suatu konferensi. Oleh karena itu, norma paradigma tentang pandangan dunia ilmiah juga dapat mempengaruhi penilaian komunitas sains tentang teori-teori yang bersaing. Berdasarkan hasil survey, sangat sedikit responden yang memiliki pandangan filosofis paradigma ilmiah sebagai aspek validasi pengetahuan ilmiah (3\% memilih $1 \mathrm{C}$ dan $1 \%$ memilih $1 \mathrm{~F})$.

7. Posisi filosofis pada aspek objektivitas dan subjektivitas

Pengetahuan ilmiah dibentuk dari proses konstruksi makna melalui objektivitas dan subjektivitas. Ilmu pengetahuan dapat dipengaruhi oleh keyakinan, nilai, penilaian, kreativitas, peluang, dan psikologi ilmuwan yang terletak pada masyarakat, budaya, dan disiplin ilmu yang melekat padanya (Sumranwanich dan Yuenyong, 2014). Subjektivitas pengetahuan ilmiah direfleksikan dalan obsewrvasi, interpretasi, penggunaan imajinasi, dan pemilihan teori oleh ilmuwan. Kuesioner VOSE mengizinkan untuk mengkategorikan posisi subjektivitas NOS yang berbeda (parsimony/penghematan, wewenang, paradigma, faktor pribadi, pengaruh sosial budaya, imajinasi, metodologi, dan netral). Berdasarkan hasil survei, ditemukan bahwa sebagian besar mahasiswa IPAFisika sebagai responden penelitian ini memiliki perspektif netral (45\% memilih 1B), pengaruh sosial budaya (35,6\% memilih $2 \mathrm{~A}$ dan $19,8 \%$ memilih $2 \mathrm{~B})$, dan imajinasi (29,6\% memilih 3A dan 22,8\% memilih 3B).

Pengetahuan ilmiah berdasarkan pada empirisme. Ilmuwan mencoba menjadi berpikiran terbuka dan menerapkan mekanisme seperti peer-review dan triangulasi data untuk meningkatkan objektivitas. VOSE mengizinkan untuk mengkategorikan posisi objektivitas yang berbeda (tidak ada pengaruh sosiokultural, tidak menggunakan imajinasi, berdasarkan fakta eksperimental, tidak ada pengaruh keyakinan pribadi, metodologi, secara keseluruhan). Namun, survei ini menemukan bahwa sebagian besar mahasiswa IPA-Fisika sebagai responden penelitian ini memiliki persepsi objektivitas ilmiah pada posisi metodologi $(69,4 \%$ memilih pernyataan 9A, 38,1\% memilih pernyataan 8E, dan 19,4\% memilih 9B) dan secara keseluruhan berdasarkan bukti empiris (25\% memilih 1A dan $18 \%$ memilih $1 \mathrm{H})$. Lebih sedikit responden yang memiliki pandangan bahwa pengetahuan ilmiah berdasarkan fakta eksperimental $(29,7 \%$ memilih 5B, 34\% memilih 6B, dan 12,4 memilih 8D) dan tidak dipengaruhi sosiokultural (8,9\% memilih 2D dan 33,7\% memilih 2D).

Sikap mahasiswa IPA-Fisika sebagai responden penelitian ini terhadap pengajaran sains dapat diketahui berdasarkan jawabannya pada kuesioner VOSE. Berdasarkan kuesioner 
VOSE, dapat diketahui sikap mahasiswa terhadap pengajaran NOS pada aspek tentativeness, hakikat observasi, metode ilmiah, dan aspek teori dan hukum.

1. Sikap mahasiswa terhadap pengajaran NOS pada aspek tentativeness

Tabel 14 menunjukkan bahwa sebagian besar mahasiswa memiliki sikap bahwa perlu untuk mengajarkan hakikat pengetahuan ilmiah (83,5\% memilih 12B dan 11,3\% memilih 12A). Hal ini menunjukkan bahwa mahasiswa IPA-Fisika memiliki sikap positif tentang pentingnya pengajaran NOS dalam pembelajaran sains.

2. Sikap mahasiswa terhadap pengajaran NOS pada aspek hakikat observasi

Tabel 13 menunjukkan bahwa lebih dari 50\% mahasiswa IPA-Fisika sebagai responden penelitian ini memiliki pandangan perlunya melatih siswa untuk membuat observasi yang objektif dalam pembelajaran IPA-Fisika $(41,8 \%$ memilih $11 \mathrm{~A}, 5,1 \%$ memilih $11 \mathrm{~B}$, dan $15,3 \%$ memilih 11C). Namun, masih ada responden yang beranggapan bahwa observasi adalah teori laden yang tidak perlu dilatihkan saat pembelajaran (sejumlah 25,5\% memilih 11E dan 9,2\% memilih 11D).

3. Sikap mahasiswa terhadap pengajaran NOS pada aspek metode ilmiah

Tabel 12 menunjukkan bahwa seluruh responden memiliki sikap bahwa dalam pembelajaran IPA-Fisika diajarkan metode ilmiah universal (10A-10F). Tidak ada satupun responden yang memilih pernyataan yang menunjukkan bahwa perlu mendorong penggunaan metode yang berbeda dalam metode ilmiah (10G-10I).

4. Sikap mahasiswa terhadap pengajaran NOS pada aspek teori dan hukum

Hasil survei mengindikasikan bahwa mahasiswa IPA-Fisika sebagai responden penelitian ini memiliki kesadaran terhadap pentingnya pengajaran sains ang berhubungan dengan perbedaan dari jenis-jenis pengetahuan ilmiah. Tabel 15 menunjukkan bahwa mayoritas responden setuju untuk mengajarkan hubungan antara hipotesis, teori, dan hukum $(26,5 \%$ memilih 13 A dan $65,3 \%$ memilih 13B).

Hasil survei tersebut menunjukkan bahwa mahasiswa IPA-Fisika masih mengalami kesulitan dalam mengkonseptualisasikan gambaran umum NOS. Hal ini dipahami karena berdasarkan penelitian sebelumnya, observasi di sekolah tingkat SMA menunjukkan bahwa siswa SMA tidak mendapatkan pengajaran NOS. Sebagian besar siswa SMA diminta membaca sendiri materi tentang hakikat sains dan dilanjutkan pada materi Fisika selanjutnya (Jauhariyah et.al, 2020). Melihat kondisi tersebut, tim penelitian sebelumnya menerapkan pembelajaran NOS dan menguji pemahaman siswa kelas X di salah satu sekolah SMA terhadap NOS. Peneliti mengalami beberapa kendala teknis saat akan melakukan survei pemahaman siswa menggunakan VNOSQ lantaran guru di sekolah tersebut belum terbiasa menggunakan instrumen angket dalam pembelajaran sehingga membutuhkan diskusi yang cukup rumit untuk mendapatkan kesempatan tersebut. Setelah itu, diperoleh bahwa pemahaman siswa terhadap NOS masih dalam kategori cukup (Jauhariyah et.al, 2020). Dengan demikian, masih diperlukan upaya dan perhatian khusus pada topik NOS dalam pembelajaran sains baik untuk siswa, guru, maupun calon guru. Melalui pemahaman yang benar terhadap NOS dan sikap positif terhadap seluruh aspek NOS, diharapkan bahwa seluruh komponen pendidikan sains (dalam hal ini guru, calon guru, dan siswa) dapat memahami NOS dengan benar.

\section{KESIMPULAN}

Berdasarkan hasil survei pandangan mahasiswa IPA-Fisika terhadap konsep NOS dan pengajaran NOS, diperoleh hasil bahwa tampaknya mahasiswa masih mengalami kesulitan untuk mengkonseptualisasikan gambaran umum NOS. Namun mahasiswa telah merasakan NOS dalam pembelajarannya. Mahasiswa IPA-Fisika sebagai responden penelitian ini memiliki sikap positif terhadap pengajaran NOS pada aspek tentativeness, hakikat observasi, serta aspek teori dan hukum. Namun, mahasiswa memiliki sikap negatif terhadap pengajaran NOS dalam sepek metode ilmiah. Mahasiswa IPA-Fisika masih harus belajar dan meneliti lebih lanjut tentang NOS agar lebih memahami konsep NOS. 


\section{DAFTAR PUSTAKA}

Abd-El-Khalick F. dan BouJaoude S. 1997. An Exploratory Study of the Knowledge Base for Science Teaching. Journal of Research in Science and Teaching, 34, 673, https://doi.org/10.1002/(SICI)1098-2736(199709)34:7\%3C673::AIDTEA2\%3E3.0.CO;2-J

Abd-El-Khalick F. dan Lederman N.G. 2000. Improving Science Teachers' Conceptions of Nature of Science: a Critical Review of the Literature. International Journal on Science Education, 22(7), 665, https://doi.org/10.1080/09500690050044044

Abd-El-Khalick F., Lederman N.G., Bell R.L., Hall R., dan Street E. 2002. J. Res. Sci. Teach. 12267

Bell R.L. 2008. Best Practices in Science Education Teaching the Nature ofScience: Three Critical Questions. (Hampton-Brown: National Geographic Learning/Cengage).

Bilican K., Tekkaya C., dan Cakiroglu J. 2012. Pre-Service Science Teachers' Instructional Planning for Teaching Nature of Science: A Multiple Case Study. Procedia-Social and Behavioral Sciences, 31, 468, doi:10.1016/j.sbspro.2011.12.088

Chen, S. 2006. Development of an Instrument to Assess Views on Nature of Science and Attitude Toward Teaching Science. Science Education, 90, 803-819, https://doi.org/10.1002/sce.20147

Chen, S. 2006. Views on science and education (VOSE) questionnaire. Asia-Pacific Forum on Science Learning and Teaching, 7(2)

Jain J., Lim B.K., dan Abdullah N. 2013. Pre-service teacher's conceptions of the Nature of Science. Procedia-Social and Behavioral Sciences, 90, 203-210, doi:10.1016/j.sbspro.2013.07.083

Jauhariyah, M. N. R., Rohmah, S.N., dan Permatasari, N.Y. 2020. The Students' Understanding Profile on Nature of Science (NOS) of Physics. Journal of Physics: Conference Series, 1491, 012056, doi:10.1088/1742-6596/1491/1/012056.

Jiang F. dan McComas W.F. 2014. Analysis of Nature of Science Included in Recent Popular Writing Using Text Mining Techniques. Science and Education, 23(9), 1785

Lederman N.G. dan Lederman J.S. 2004. Revising Instruction to Teach Nature of Science. The Science Teacher, 71(9), 36.

Lederman, N.G. 1992. Students' and teachers' conceptions of the nature of science: A review of the research. Journal of Research in Science Teaching, 29, 331-359, https://doi.org/10.1002/tea.3660290404

McComas W.F. 1996. Ten myth of science: Reexamining what we think we know about the nature of science. School Science and Mathematics, 96, 10-16.

McComas W.F. 2015. The Nature of Science \& the Next Generation of Biology Education. The American Biology Teacher, 77(7), 485-491.

Mihladız G. dan Doğan A. 2014. Science Teachers' Views about NOS and the Place of NOS in Science Teaching. Procedia-Social and Behavioral Sciences, 116, 3476-3483, doi: 10.1016/j.sbspro.2014.01.787.

OECD. 2013. PISA 2015 Draft Science Framework. https://www.oecd.org/pisa/pisaproducts/Draft\%20PISA\%202015\%20Science\%20Framewor $\mathrm{k} \% 20$.pdf

OECD. 2015. PISA 2015 Results in Focus. http://iave.pt/images/FicheirosPDF/Estudos Internacionais/PISA_2015 Focus v6.pdf

Sangsa-ard R, Thathong K, and Chapoo S 2014 Procedia-Social and Behavioral Science Volume 116 No. 381

Schleicher, A. 2019. PISA 2018 Insights and Interpretations. https://www.oecd.org/pisa/PISA\%202018\%20Insights\%20and\%20Interpretations\%20FINA L\%20PDF.pdf 
Sumranwanich W. dan Yuenyong C. 2014. Graduate students' concepts of nature of science (NOS) and attitudes towards teaching NOS. Procedia-Social and Behavioral Sciences, 116, 2443-2452, doi:10.1016/j.sbspro.2014.01.589 